Gut, 1982, 23, 108-114

\title{
Alkaline phosphatase synthesis and properties of subcellular organelles during in vitro culture of jejunal biopsies from control subjects and patients with coeliac disease
}

\author{
P E JONES, ${ }^{*}$ C L'HIRONDEL $\dagger$ AND T J PETERS $\ddagger$ \\ From the Department of Medicine, Royal Postgraduate Medical School, London, \\ and Division of Clinical Cell Biology, MRC Clinical Research Centre, Harrow, Middlesex
}

SUMMARY Portions of jejunal biopsies from control subjects and from patients with coeliac disease were cultured for 24 hours using an in vitro organ culture technique. Alkaline phosphatase activity was measured in the tissue and medium before and after culture; enzyme activities were expressed per $\mu \mathrm{g}$ tissue DNA. The increase in enzyme activity during the culture period was taken to represent net enzyme synthesis. Alkaline phosphatase synthesis by mucosa from patients with untreated glutensensitive coeliac disease and by mucosa from patients with non-responsive coeliac disease was significantly less than that by normal mucosa. Alkaline phosphatase synthesis by mucosa from patients with treated gluten-sensitive coeliac disease was greater than that by untreated coeliac mucosa but was less than normal mucosa. Sequential studies of alkaline phosphatase synthesis by jejunal mucosa from seven patients with coeliac disease, before and after succesful treatment by gluten withdrawal, showed an increase in synthesis in all patients. Study, by analytical subcellular fractionation with sucrose density gradient centrifugation, of the properties of the organelles of cultured control tissue showed good preservation of their integrity. A striking finding, however, was the decrease in malate dehydrogenase with a corresponding marked increase in lactate dehydrogenase. This would be expected to be followed by a shift from aerobic to anaerobic metabolism. Analytical subcellular fractionation of cultured mucosa from patients with coeliac disease gave similar conclusions. There was, however, a marked improvement of the brush border abnormalities, characteristic of coeliac disease, during culture with increased enzyme activities and membrane equilibrium density in the sucrose gradients.

Jejunal biopsies from patients with untreated coeliac disease show a reduction in activity of the brush border enzyme alkaline phosphatase. ${ }^{1-3}$ Activity of this enzyme increases when gluten is removed from the diet and villous regeneration occurs. ${ }^{4}$ Alkaline phosphatase activity of cultured jejunal mucosa has also been used as a marker of in vitro gluten toxicity in experiments designed to investigate the pathogenesis of coeliac disease. ${ }^{5-7}$

\footnotetext{
*Present address: University Department of Gastroenterology, Manchester Royal Infirmary, Oxford Road, Manchester M13 9WL. +Present address: Departement de Gastroenterologie, Centre Hospitalier Universitaire, 14040, Caen Cedex, France.

$\ddagger$ Address for correspondence: Dr T J Peters, Division of Clinical Cell Biology, MRC Clinical Research Centre, Watford Road, Harrow, Middlesex HA1 3UJ, UK.

Received for publication 28 July 1981
}

These latter experiments have yielded conflicting results which may be due to (1) the use of an unsatisfactory reference parameter (tissue protein) for the expression of enzyme activity after culture; (2) failure to take account of loss of enzyme activity into the culture medium, ${ }^{89}$ and (3) instability of the enzyme on storage.

A reliable method of in vitro culture of human small intestine has been developed in this laboratory by the combination of wire mesh suspension and roller tube techniques. ${ }^{20}$ In these studies it was shown that total (tissue and medium) DNA remains constant during culture. We have therefore assayed alkaline phosphatase activity in fresh jejunal tissue both before culture and in tissue and medium after culture expressing the results per 
$\mu \mathrm{g}$ total DNA. Net alkaline phosphatase synthesis was determined in jejunal mucosa from patients with untreated coeliac disease, treated glutensensitive coeliac disease and treated nonresponsive coeliac disease, in order to investigate the pathogenesis of these disorders. In addition the marker enzyme activities of the principal organelles of jejunal mucosa and their distribution in sucrose gradients after analytical subcellular fractionation were determined for tissue from control subjects and patients with untreated gluten-sensitive coeliac disease in order to study the alterations in the properties of the subcellular organelles after culture.

\section{Methods}

PATIENTS

Jejunal biopsies were obtained with a WatsonCrosby capsule $10 \mathrm{~cm}$ distal to the ligament of Trietz from patients with untreated coeliac disease (11), treated gluten-sensitive coeliac disease (13) and treated non-responsive coeliac disease (five). In addition, seven patients with untreated coeliac disease were studied before and after responding to gluten withdrawal. Patients undergoing investigation for gastrointestinal symptoms whose jejunal mucosa was morphologically normal served as the control group (nine patients). Informed consent was obtained from all patients, and this study has

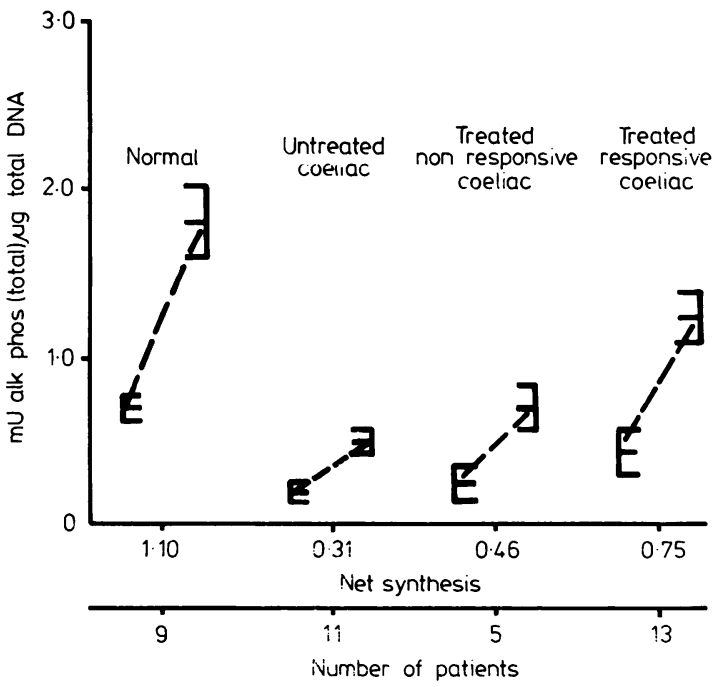

Fig. 1 Total (tissue and medium) alkaline phosphatase activity before and after 24 hour culture. Values are shown as mean $\pm S D$. Net synthesis over 24 hours is shown on the abscissa and number of patients studied is shown below. been approved by the local Ethical Committee. The biopsies were divided into pieces for (1) routine histology; (2) assay of alkaline phosphatase activity, and (3) in vitro organ culture. Portions of the biopsies were cultured for 24 hours as described previously. ${ }^{10}$ After culture, each piece of tissue was inspected with a dissecting microscope and alkaline phosphatase activity was measured fluorimetrically with 4 methyl umbelliferyl phosphate as substrate. ${ }^{3}$ DNA was measured in tissue and medium by the method of Le Pecq and Paoletti" ${ }^{11}$ with calf thymus DNA as standard. Protein was assayed by the fluorimetric method described previously ${ }^{12}$ with bovine serum albumin as the standard. The increment of alkaline phosphatase activity during the 24 hour period was taken as a measure of net enzyme synthesis. Analytical subcellular fractionation and organelle marker enzyme analysis ${ }^{12}$ of jejunal biopsies were carried out both before and after culture. Statistical analysis of results was carried out with the Wilcoxon rank sum test.

\section{Results}

ALKALINE PHOSPHATASE ACTIVITY IN CULTURED MUCOSA (Fig. 1)

Alkaline phosphatase synthesis by untreated gluten-sensitive coeliac mucosa, $0.31 \mathrm{mU} / \mu \mathrm{g}$ DNA/ 24 h (95\% confidence limits $0 \cdot 25-0.42)$ was significantly less than normal mucosa, $1.10 \mathrm{mU} / \mu \mathrm{g}$ DNA/24 h (95\% confidence limits 0.76-1.62, $\mathrm{P}<0.01$ ). Alkaline phosphatase synthesis by treated non-responsive coeliac mucosa, $0.46 \mathrm{mU} / \mu \mathrm{g}$ DNA/24 h, was lower than normal mucosa $(P<0.01)$ but greater than untreated coeliac mucosa $(\mathrm{P}<0.05)$. Alkaline phosphatase synthesis by treated coeliac mucosa, $0.75 \mathrm{mU} / \mu \mathrm{g}$ DNA $/ 24 \mathrm{~h}$, (95\% confidence limits $0.51-1.06)$ was greater than untreated coeliac mucosa $(P<0.01)$ but less than normal mucosa $(\mathrm{P}<0.01)$.

Sequential studies on seven untreated patients before and after successful gluten withdrawal showed a significant increase in alkaline phosphatase synthesis (Fig. 2): mean value before treatment, $0.48 \mathrm{mU} / \mu \mathrm{g} \mathrm{DNA} / 24 \mathrm{~h}$, increasing, after treatment, to $0.96 \mathrm{mU} / \mu \mathrm{g} \mathrm{DNA} / 24 \mathrm{~h}$. The ratio of tissue to medium alkaline phosphatase activity after 24 hours' culture was, for normal mucosa, 0.47 , for untreated coeliac mucosa, 0.45 , for treated non-responsive coeliac mucosa, 0.42 , and for treated responsive coeliac mucosa, 0.48 . These differences are not significant.

The ratio of tissue to medium DNA after 24 hours culture was 1.63 for normal mucosa and 1.26 for untreated coeliac mucosa (Fig. 3) $(P<0.05)$. 


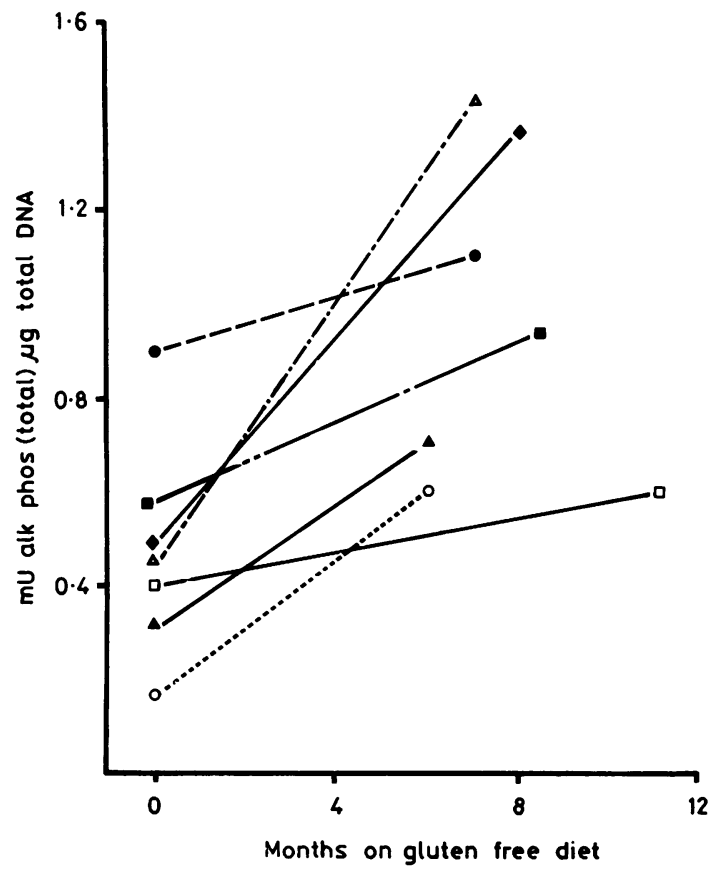

Fig. 2 Synthesis of alkaline phosphatase before and after treatment by gluten withdrawal in seven patients. Values shown indicate net alkaline phosphatase synthesised. Each line joins values for one patient before and during treatment. The key identifies patients and indicates jejunal morphology before and on treatment: $\square$ JM flat:pva. $\square D T$ flat:pva. O VC flat:pva. $\triangle J D$ flat:pva. $\bullet A B$ flat:pva. $\triangle B T$ flat:pva. $\triangle M C$ pva:normal.

Table Enzymic activities of human jejnum before and after organ culture

\begin{tabular}{|c|c|c|c|c|c|}
\hline \multirow[t]{2}{*}{ Organelle and marker enzyme } & \multirow[t]{2}{*}{ EC No. } & \multicolumn{2}{|l|}{ Control tissue } & \multicolumn{2}{|c|}{ Untreated coeliac mucosa } \\
\hline & & Pre-culture & Post-culture & Pre-culture & Post-culture \\
\hline $\begin{array}{l}\text { Brush border: } \\
\text { alkaline phosphatase }\end{array}$ & 3.1.3.1 & $\begin{array}{l}64 \cdot 7 \pm 6 \cdot 3 \\
(15)\end{array}$ & $\begin{array}{l}75.5 \pm 5.9 \\
(6) P>0.05\end{array}$ & $\begin{array}{l}16 \cdot 9 \pm 1 \cdot 5 \\
(11)\end{array}$ & $\begin{array}{l}33.2 \pm 4.3 \\
\text { (5) } \mathrm{P}<0.001\end{array}$ \\
\hline $\begin{array}{l}\text { Brush border: } \\
\gamma \text { glutamyl transferase }\end{array}$ & 2.3.2.2 & $\begin{array}{l}12 \cdot 1 \pm 1 \cdot 4 \\
\text { (i1) }\end{array}$ & $\begin{array}{l}12 \cdot 8 \pm 3.0 \\
(6) P>0.05\end{array}$ & $\begin{array}{l}5.45 \pm 0.87 \\
(7)\end{array}$ & $\begin{array}{l}10.9 \pm 1.17 \\
\text { (4) } P<0.001\end{array}$ \\
\hline $\begin{array}{l}\text { Brush border: } \\
\text { total } \alpha \text {-glucosidase } \\
\text { pH } 6.0\end{array}$ & 3.2 .1 .20 & $\begin{array}{l}9 \cdot 54 \pm 1 \cdot 0 \\
(13)\end{array}$ & $\begin{array}{l}10.4 \pm 1.4 \\
(6) P>0.05\end{array}$ & $\begin{array}{l}3 \cdot 10 \pm 0 \cdot 3 \\
(9)\end{array}$ & $\begin{array}{l}6.79 \pm 1.80 \\
\text { (4) } P<0.05\end{array}$ \\
\hline $\begin{array}{l}\text { Brush border: } \\
\mathrm{Zn}^{2+} \text {-resistant } \alpha \text {-glucosidase } \\
\text { pH } 6.0\end{array}$ & 3.2 .1 .20 & $\begin{array}{l}8.94 \pm 1.03 \\
(8)\end{array}$ & $\begin{array}{l}5.60 \pm 1.7 \\
(4) P>0.05\end{array}$ & $\begin{array}{l}1.03 \pm 0.32 \\
(4)\end{array}$ & $\begin{array}{l}4.49 \pm 0.42 \\
\text { (3) } P<0.001\end{array}$ \\
\hline $\begin{array}{l}\text { Peroxisome: } \\
\text { catalase }\end{array}$ & 1.11.1.6 & $\begin{array}{l}79 \cdot 9 \pm 5 \cdot 5 \\
(15)\end{array}$ & $\begin{array}{l}81 \cdot 7 \pm 5.3 \\
(5) P>0.05\end{array}$ & $\begin{array}{l}99 \cdot 1 \pm 12 \cdot 1 \\
(8)\end{array}$ & $\begin{array}{l}63.0 \pm 18.0 \\
\text { (4) } P>0.05\end{array}$ \\
\hline $\begin{array}{l}\text { Lysosome: } \\
N \text {-acetyl- } \beta \text {-glucosaminidase }\end{array}$ & 3.2.1.30 & $\begin{array}{l}6.08 \pm 0.47 \\
(14)\end{array}$ & $\begin{array}{l}7.66 \pm 1.07 \\
(5) P>0.05\end{array}$ & $\begin{array}{l}7 \cdot 51 \pm 0 \cdot 15 \\
(10)\end{array}$ & $\begin{array}{l}6.18 \pm 0.75 \\
\text { (4) } P>0.05\end{array}$ \\
\hline $\begin{array}{l}\text { Mitochondria/cytosol: } \\
\text { malate dehydrogenase }\end{array}$ & 1.1.1.37 & $\begin{array}{l}3720 \pm 310 \\
(15)\end{array}$ & $\begin{array}{l}1960 \pm 450 \\
\text { (6) } \mathrm{P}<0.002\end{array}$ & $\begin{array}{l}2150 \pm 220 \\
(8)\end{array}$ & $\begin{array}{l}1862 \pm 110 \\
(5) P<0.05\end{array}$ \\
\hline $\begin{array}{l}\text { Cytosol: } \\
\text { lactate dehydrogenase }\end{array}$ & 1.1.1.27 & $\begin{array}{l}387 \pm 40 \\
(5)\end{array}$ & $\begin{array}{l}1045 \pm 143 \\
\text { (5) } P<0.001\end{array}$ & $\begin{array}{l}530 \pm 21 \\
(4)\end{array}$ & $\begin{array}{l}719 \pm 73 \\
\text { (4) } P<0.02\end{array}$ \\
\hline $\begin{array}{l}\text { Endoplasmic reticulum: } \\
\text { total } \alpha \text {-glucosidase } \\
\text { pH 8.0 }\end{array}$ & 3.2 .1 .20 & $\begin{array}{l}1 \cdot 13 \\
(14)\end{array}$ & $\begin{array}{l}1.41 \pm 0.40 \\
(4) P>0.05\end{array}$ & $\begin{array}{l}0.957 \pm 0.131 \\
(8)\end{array}$ & $\begin{array}{l}1.51 \pm 0.28 \\
(5) P>0.05\end{array}$ \\
\hline $\begin{array}{l}\text { Endoplasmic reticulum: } \\
\mathrm{Zn}^{2+} \text {-sensitive } \alpha \text {-glucosidase } \\
\text { pH } 6.0\end{array}$ & 3.2.1.20 & $\begin{array}{l}1.96 \pm 0.43 \\
(10)\end{array}$ & $\begin{array}{l}1.74 \pm 0.39 \\
(4) P>0.05\end{array}$ & $\begin{array}{l}1 \cdot 73 \pm 0 \cdot 24 \\
(4)\end{array}$ & $\begin{array}{l}1.20 \pm 0.08 \\
\text { (3) } \mathrm{P}<0.05\end{array}$ \\
\hline $\begin{array}{l}\text { Basal-lateral membrane: } \\
\text { 5'nucleotidase }\end{array}$ & 3.1.3.5 & $\begin{array}{l}41 \cdot 1 \pm 4 \cdot 1 \\
(8)\end{array}$ & $\begin{array}{l}94.3 \pm 6.9 \\
\text { (4) } P<0.001\end{array}$ & $\begin{array}{l}38 \cdot 1 \pm 4 \cdot 0 \\
(4)\end{array}$ & $\begin{array}{l}24.3 \pm 5.1 \\
\text { (3) } P<0.05\end{array}$ \\
\hline
\end{tabular}

Specific activity expressed as mean $\pm \mathrm{SE}$ (mUnits/mg protein). Number of specimens assayed is shown in parentheses. Preculture data taken from reference 4. Statistical analysis compares pre- and post-culture values for each patient group. 


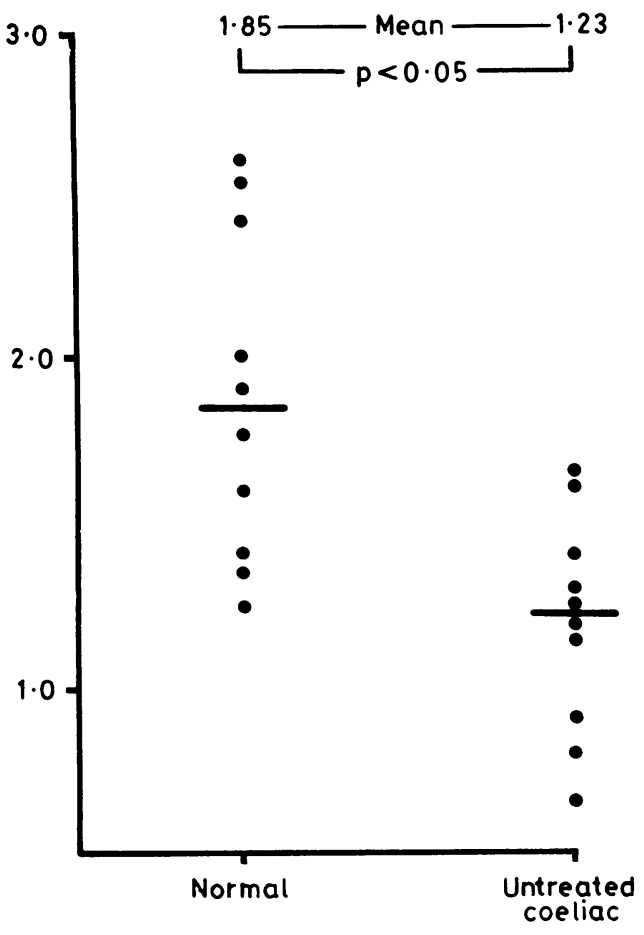

Fig. 3 Ratio of DNA in tissue and culture medium after 24 hour culture of normal and untreated gluten-sensitive coeliac mucosa.

\section{ENZYMIC ANALYSIS AND SUBCELLULAR}

\section{FRACTIONATION OF CULTURED MUCOSA}

The Table shows the activities of the various organelle marker enzymes in jejunal mucosa from both control subjects and patients with untreated gluten-sensitive coeliac disease. The activity of the four brush border enzymes is markedly lower in the patients with coeliac disease compared with the control subjects. There is, however, a differential response to culture. Thus with control tissue there is no significant change in brush border enzyme activity but all these enzymes show a striking increase in cultured coeliac mucosa.

There are no significant differences in the activities or response of the peroxisomal marker enzyme. Although the preculture lysosomal enzyme $\mathrm{N}$-acetyl- $\beta$-glucosaminidase is higher in the coeliac mucosa, there are no significant changes in response to culture. In both groups the activity of malate dehydrogenase shows a marked decrease after culture but, in contrast, lactate dehydrogense shows a striking rise. The two endoplasmic reticulum marker enzymes show little differences except that the decrease in activity of the highly specific marker $\mathrm{Zn}^{2+}$-sensitive $\alpha$-glucosidase after

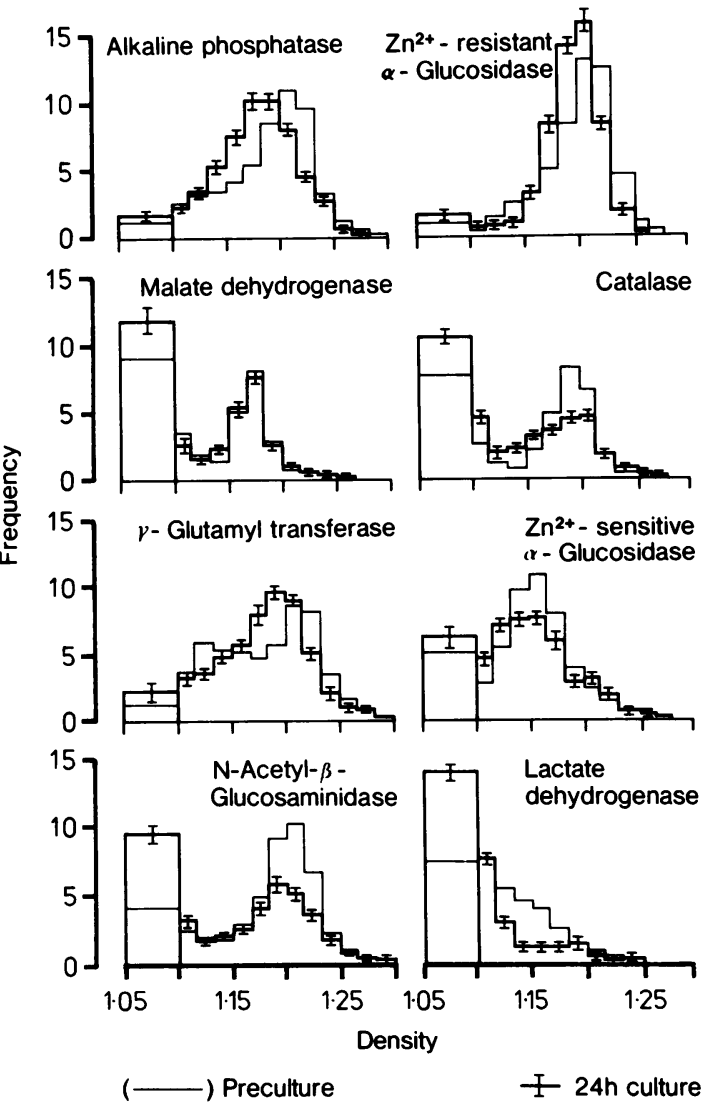

Fig. 4 Analytical subcellular fractionation by sucrose density gradient centrifugation of $6000 \mathrm{~g}$ min supernatant from control jejunum before (-) and after $(-) 24$ hour culture. Graphs show frequency-density histograms where frequency is defined as that proportion of total recovered enzyme in the individual fraction divided by the density span of that fraction. The activity over density span $1 \cdot 05-1 \cdot 10 \mathrm{~g}$ $\mathrm{cm}^{-3}$ represents, over an arbitrary interval, enzyme remaining in the sample layer and presumed to reflect soluble activity. The percentage recovered activities (mean of three to five experiments) for the cultured tissue are: alkaline phosphatase, 86; $\mathrm{Zn}^{2+}$-resistant $\alpha$-glucosidase, 82; malate dehydrogenase, 84; catalase, 104; $\gamma$-glutamyl transferase, 101; $\mathrm{Zn}^{2}+$-sensitive $\alpha$-glucosidase, $108 ; \mathrm{N}$-acetyl- $\beta$ glucosaminidase, 86; lactate dehydrogenase, 104. Pre-culture data taken from Peters et al.4

culture of coeliac mucosa just reaches statistical significance. The response of the basal-lateral marker enzyme differs markedly between the two patient groups. Although the pre-culture activities are similar, the control tissue shows a marked increase but the coeliac mucosa shows a significant fall in enzyme activity. This is in striking contrast with the changes in the brush border enzyme 
alterations.

Figure 4 compares the sucrose density gradient distribution of the principal organelle marker enzymes of normal jejunal mucosa before and after 24 hour culture. There are small differences in the distributions but the results indicate good preservation of organelle integrity during the period of culture. The three brush border marker enzymes alkaline phosphatase, $\mathrm{Zn}^{2+}$-resistant $\alpha$-glucosidase, and $\gamma$-glutamyl transferase show a small decrease in equilibrium density. The other organelle marker enzymes mitochondria (malate dehydrogenase), peroxisomes (catalase), and lysosomes ( $\mathrm{N}$-acetyl- $\beta$ glucosaminidase) all show a small increase in soluble compared with particulate activity but, apart form the marked fall in total malate dehydrogenase activity, there is little evidence of organelle damage. The endoplasmic reticulum enzyme shows a small decrease in median density suggesting a decrease in the ratio of rough to smooth reticulum. The gradient distribution of lactate dehydrogenase is similar in the control and cultured tissue, with most of the activity remaining in the sample layer as soluble protein.

Figure 5 shows the distribution of the organelle marker enzymes when mucosa from patients with untreated coeliac disease is subjected to analytical subcellular fractionation. The most striking finding is the partial restoration of the brush border markers toward normal. Coeliac mucosa is characterised by a marked reduction in brush border enzyme activity and a striking decrease in equilibrium density of this organelle. Both these abnormalities are partially corrected after culture. The other organelles show minor alterations similar to those found when normal tissue is cultured

\section{Discussion}

These data demonstrate that during the period of culture there is an increase in total alkaline phosphatase activity in all patient groups. Previous workers have shown that the increase in alkaline phosphatase activity of the cultured tissue can be prevented by the protein synthesis inhibitor puromycin..$^{5}$ It is likely, therefore, that this increase in enzyme activity is due to net synthesis of new enzyme rather than activation of latent activity, although the possibility that the induced enzyme protein has an increased specific activity has not been excluded. The reduced synthesis of alkaline phosphatase shown by untreated coeliac mucosa compared with control may be due to the relative immaturity of the epithelial cells of the atrophic small intestine or due to a toxic effect of gluten or its products on these cells. Conversely, the increase in

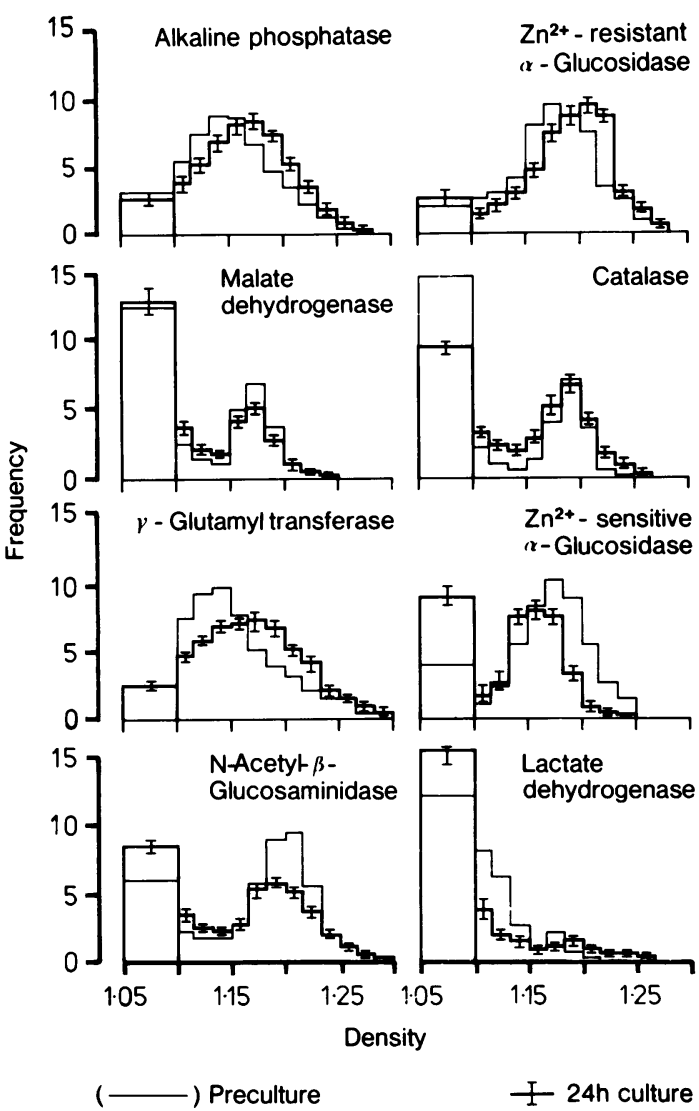

Fig. 5 Analytical subcellular fractionation by sucrose density gradient centrifugation of $6000 \mathrm{~g}$ min supernatants from untreated coeliac disease before $(-)$ and after $(-)$ 24 hour culture. The percentage recovered activities (mean three to five experiments) for the cultured tissue are: alkaline phosphatase, 80; $\mathrm{Zn}^{2+}$-resistant $\alpha$-glucosidase, 84; malate dehydrogenase, 106; catalase, 80; $\gamma$-glutamyl transferase, 96; $\mathrm{Zn}^{2+}$-sensitive $\alpha$-glucosidase, $100 ; \mathrm{N}$-acetyl- $\beta$ -

glucosaminidase, 103; lactate dehydrogenase, 96. For additional details see legend to Fig. 4.

alkaline phosphatase synthesis shown by treated gluten-sensitive coeliac mucosa may reflect the increasing proportion of mature enterocytes in regenerating intestinal epithelium or the absence of gluten toxicity on the enterocyte. Non-responsive coeliac mucosa from patients who have received a gluten-free diet for prolonged periods synthesises alkaline phosphatase only slightly faster than untreated coeliac mucosa and thus it is more likely that the reduced synthesis rate reflects cell immaturity. The high medium enzyme activity at the end of 24 hours' culture in all four patient groups 
indicates that, during the culture period, there is a progressive release of enzyme activity from the enterocyte into the culture medium. This increase in enzyme activity in the medium has been shown to be linear over the 24 hour period and does not show the same time-relationship as the increase in DNA in the medium. ${ }^{8}$ After a period of organ culture there is a layer of mucus-like material covering the 'luminal' aspect of the cultured tissue. In the organ culture technique we have developed, this layer of mucus is washed into the culture medium at the end of culture and any enzyme activity present is assayed with the culture medium. It is likely that the alkaline phosphatase activity present in the culture medium represents enzyme activity present in desquamated epithelial cells, and enzyme lost from or secreted by the brush border.

The sequential studies in the patients studied before and after successful treatment with gluten withdrawal show that in all seven patients there is an increase in the rate of alkaline phosphatase synthesis after the villous regeneration. The finding also indicates that the increase in alkaline phosphatase synthesis rate reflects an increase in maturity of the enterocytes.

We have found that the mean percentage rise in alkaline phosphatase in cultured normal mucosa is $4 \%$ and in cultured untreated coeliac mucosa $70 \%$. Assuming the enzyme activity increases linearly with respect to time, this is less than that found by Falchuk et $a l^{5}$ who demonstrated, at 48 hours, a percentage increase of $46 \%$ for normal mucosa and $240 \%$ for untreated coeliac mucosa but similar to these reported by Stevens and colleagues. ${ }^{13}$ This discrepancy could be due to the use of different parameters for the expression of enzyme activity at the end of culture. We have used total DNA as the reference parameter but, when our results are calculated per $\mathrm{mg}$ tissue protein, values of $35 \%$ for normal mucosa and $125 \%$ for untreated coeliac mucosa are obtained which are in reasonable agreement with the previously reported studies. The higher post-culture piece to medium DNA ratio found with normal mucosa compared with untreated coeliac mucosa probably reflects the differing rate of cell loss from untreated coeliac mucosa into the culture medium. ${ }^{14}$

The results of analytical subcellular fractionation before and after culture indicate that when normal mucosa is cultured for 24 hours there is a slight decrease in the density of the brush border. This is probably due to loss of glycoprotein from the brush border into the culture medium, or it may reflect a shedding of the more superficial mature enterocytes compared with the immature crypt cells. The results for the other marker enzymes indicate good preservation of organelle integrity and this is in agreement with ultrastructural studies. ${ }^{8}$

The alterations in levels of lactate and malate dehydrogenase are of interest. They must be reflected by a major change in the metabolic processes of the tissue and would be consistent with a change in the proportions of aerobic to anaerobic metabolism in culture. They also indicate that the use of organ culture procedures for studying intermediary metabolism of intestinal mucosa are likely to produce misleading results.

When untreated coeliac mucosa is cultured, there is an increase in density and enzyme content of the brush border peak. Morphological improvement in the brush border of cultured coeliac mucosa has been found by light and electron microscopy by other workers. ${ }^{571015}$ These findings may well prove to be important when assessing the toxic effect of gliadin in vitro and in determining the pathogenesis of the coeliac lesion.

We wish to thank Dr C C Booth for his interest in this work and Ms R Greensted for secretarial assistance.

\section{References}

'Ferguson A, Watson WC, Maxwell JD, Fell GS. Alkaline phosphatase levels in normal and diseased small bowel. Gut 1968; 9:96-8.

${ }^{2}$ Campbell CB, Cowen AE, McGeary HM, Gaffney TJ. Mucosal enzyme activity as a quantitative index of early functional improvement in the management of coeliac disease and other small intestinal disease. Aust $\mathrm{NZ} \mathrm{J} \mathrm{Med}$ 1972; 2:220-27.

${ }^{3}$ Peters TJ, Heath JR, Wansbrough-Jones MH, Doe WF. Enzyme activities and properties of lysosomes and brush borders in jejunal biopsies from control subjects and patients with coeliac disease. Clin Sci Mol Med 1975; 48:259-67.

${ }^{4}$ Peters TJ, Jones PE, Wells G. Analytical subcellular fractionation of jejunal biopsy specimens; enzyme activities, organelle pathology and response to gluten withdrawal in patients with coeliac disease. Clin Sci Mol Med 1978; 55:285-92.

5Falchuk ZM, Gebhard RL, Sessoms C, Strober W. An in vitro model of gluten sensitive enteropathy. Effect of gliadin on intestinal epithelial cells of patients with glutensensitive enteropathy in organ culture. J Clin Invest 1974; 53:487-500.

${ }^{6}$ Jos J, Lenoir G, De Ritis G, Rey J. In vitro pathogenetic studies of coeliac disease. Scand J Gastroenterol 1975; 10:121-8.

${ }^{7}$ Hauri HP, Kedinger M, Haffen K, Gaze H, Hadorn B, Hekkens W. Re-evaluation of the technique of organ culture for studying gluten toxicity in coeliac disease. Gut 1978; 19:1090-8.

${ }^{8}$ Mitchell JD, Mitchell J, Peters TJ. Enzyme changes in 
human small bowel mucosa during culture in vitro. Gut 1974; 15:805-11.

9Jones PE, L'Hirondel C, Peters TJ. Sequential biochemical studies in coeliac disease using jejunal organ culture techniques. In: Perspectives in Coeliac Disease. McNicholl BM, McCarthy CF, Fottrell PF, eds. Lancaster: MTP Press. 1978: 111-8.

${ }^{10}$ L'Hirondel C, Doe WF, Peters TJ. Biochemical and morphological studies on human jejunal mucosa maintained in culture. Clin Sci Mol Med 1976; 50:425-9.

${ }^{11}$ Le Pecq JB, Paoletti C. A new fluorimetric method for RNA and DNA determination. Analyt Biochem 1966; 17:100-7.
${ }^{12}$ Peters TJ. The analytical subcellular fractionation of jejunal biopsy specimens. Methodology and characterisation of the organelles in normal tissue. Clin Sci Mol Med 1976; 51:557-574.

${ }^{13}$ Stevens FM, Keane R, Fottrell PF, McNicholls B, McCarthy CF. Organ culture of coeliac and non-coeliac small intestinal mucosa. Irish J Med Sci 1978; 147:11-4.

${ }^{14}$ Jones PE, Peters TJ. DNA synthesis by jejunal mucosa in responsive and non-responsive coeliac disease. $\mathrm{Br}$ Med J 1978; 1:1130-1.

${ }^{15}$ Trier JS, Browning TH. Epithelial cell renewal in cultured duodenal biopsies in coeliac sprue. $N$ Engl J Med 1970;283:1245-50. 